\title{
The Role of School Principal as Instructional Leader: The Case of Shambu Primary School
}

\author{
Mulugeta Wende Geleta \\ Department of Educational Planning and Management, Addis Ababa University, Addis Ababa, Ethiopia \\ Email: mulugetawende@yahoo.com
}

Received 9 August 2015; accepted 25 August 2015; published 31 August 2015

Copyright (C) 2015 by author and OALib.

This work is licensed under the Creative Commons Attribution International License (CC BY). http://creativecommons.org/licenses/by/4.0/

(c) (i) Open Access

\section{Abstract}

The purpose of this study is to explore the practices of primary school principal's role as instructional leader - the case of Shambu Primary School. To investigate the issue under consideration, the study was guided by qualitative case study. The guiding questions for the study were: what are the practices of principal's role as instructional leader at Shambu Primary School? How does principal fulfill his/her instructional leadership role? And which activities do principals as instructional leaders engage in so as to improve the instructional activities in the school? Semi-structured interview, focus group discussion, observation and document analyses were used as data gathering tools. On their contribution for the data sources, two principals, two heads of departments, two teachers and the school's students' council were selected using purposive sampling for interviews and group discussion. The finding of the study revealed that the administrative tasks took much of principals' time rather than instructional activities. Furthermore, it was found that the principals gave less emphasis for: instructional supervision, extra-curricular activities, teachers' training and development, provision of instructional materials and protection of teaching time. For school to be successful, the principal has to balance the administrative tasks and instructional tasks. Finally, it was recommended that the principals need to be trained in school management and leadership in order to be competent as instructional leader along with suggestions for further empirical investigation.

\section{Keywords}

Instructional Leadership, Primary School, School Principal

Subject Areas: Education

\section{Introduction}

The Ethiopia Education and Training Policy [1] clearly stipulates that, “educational management will be decen- 
tralized to create the necessary condition to expand, enrich and improve the relevance, quality, accessibility and equity of education and training in the country.” To address this issue, Ethiopian Ministry of Education [2] has developed general education quality improvement program (GEQIP) that comprises six programs of which management and leadership program is among others. For instance, the Ethiopian Ministry of Education stated that the quality of education depends on the presence of competent and committed school principals [3]. In the same vein, different researchers (e.g., [4] [5]) asserted that principal's leadership role is critical to the effectiveness of the school toward educating its students. As [6] elaborates, the major tasks of the school principal as instructional leader include: determining objective, programme coordination, being didactic leader, organizing enrichment programs, undertaking evaluation and examinations, taking remedial steps, and creating conducive school climate. Similarly, [7] has stated instructional leaders' role as setting clear goals, allocating resources to instruction, managing the curriculum, monitoring lesson plans and evaluating teachers. In an effort to achieve these functions school principals need to have the theoretical knowledge, skill and adequate experiences and various trainings on school leadership and management [8].

The importance of instructional leadership was recognized as early as the late 1970s, yet it was not well defined [9]. As Hallinger cited in [10] contends that the term instructional leadership has consistently suffered from conceptual and practical limitations, because the term means different things to different people and transforming practice takes a longer time than scholars and administrators have patience for. From the aforementioned evidences, researchers and scholars acknowledge that there is no single clear definition of instructional leadership or specific guideline as to what a principal as an instructional leader does in a school. This lack of clarity and consistency in its concept has resulted in part of the problem. Despite leadership involving a diverse number of activities and processes and although it is differentiated in its character, instructional leadership is central to successful school leadership [11]. However, research on the roles of school principals as instructional leader and its implication for quality of teaching and learning have not yet been clearly established; a problem has emerged that needs further study. Hence, it is essential to explore the practices of principal as instructional leader in primary school since this sector is the base for upper sectors of the educational system.

\section{Statement of the Problem}

The evaluation made by Ethiopian ministry of education [8] on the implementation of education sector development program (ESDP) III (2005/2006-2010/2011) revealed that one of the challenges of Ethiopian education sector that need to be addressed in the plan of ESDP IV (2010/2011-2014/2015) is an improvement in student achievement through a consistent focus on the enhancement of the teaching and learning process and the transformation of the school into a motivational and child-friendly learning environment. In order to address this challenge the school principals are expected to work on implementing the curriculum, developing the staff, coordinating and working with the community toward school improvement and creating conducive teaching and learning environment in the school. Researchers (e.g., [7] [9]) argued that even though instructional leadership is critical in the realization of effective schools, it is seldom practiced. Among the many tasks that principals perform; only one-tenth are devoted to providing instructional leadership. From these evidences it is clearly understood that the principal's instructional leadership role is not given the attention it deserves. Globally, many studies (e.g., [7] [10] [12] [13]) were conducted on the different aspects of instructional leadership using different research approaches and methods. For instance, such as researchers [10] have conducted a qualitative study to ascertain how principals understand and carried out their role as instructional leader. Another study conducted by [12] directly examined American teachers' perspectives on how principals' characteristics promote teaching and learning in schools. Recently qualitative studies conducted by [7] [10] examined principals' role in providing instructional leadership in rural high schools in South Africa and investigated how principals perceive their roles as instructional leaders in the Gauteng Province of South Africa respectively. In these abovementioned studies much of the sources of empirical data were ether principals or teachers and did not include principals, deputy principals, teachers and students as participants of their studies. It is difficult to know what effective instructional leadership role mean unless the study includes these stakeholders' perspectives. To my knowledge there was scarce research conducted on practices of primary school principals' role as instructional leader in Ethiopia in general and in this study area in particular.

Even through, changes and education reforms have been made in Ethiopian education system, my experience that I had as an expert of zone education office of the study area helped me to think critically about the problems 
principal's encountered in practicing instructional leadership roles. Hence, the purpose of this study is to explore the practices that primary school principal as instructional leader, need to engage in so as to improve the teaching and learning by exploring principal's instructional leader roles and identifying the strategies that equip principals for effective instructional leadership. In order to realize this objective the study was guided by the following research questions. How do principal fulfill his/her instructional leadership role? Which activities do principals as instructional leaders engage in so as to improve teaching and learning?

\section{Review of Related Literature}

\subsection{Instructional Leadership Conceptualizing}

The importance of instructional leadership was recognized in the 1970s, yet it was not well understood due to the term defined differently by different researchers [7] [9]. From the review of literature [14] found two views of scholars on instructional leadership. These are the "narrow" conception-those actions that are directly related to teaching and learning or observable behaviors such as class room supervision and the "broad" conception which entails all leadership activities that affect student learning. Emphasizing the concept of instructional leadership [11] describes that it is likely to be more effective when it is conceptualized as "broad" rather than "narrow" because it increases the scope for other leaders to play a role as well as the principal recognizes how social organizations operate. From these aforementioned different concepts of instructional leadership researchers and scholars acknowledge that there is no single clear definition of instructional leadership or specific guideline as to what a principal as an instructional leader does in a school.

\subsection{Principal as Instructional Leader}

The principal as instructional leader actively promotes more effective practices in the teaching and learning processes and recognizing instructional priorities rather than by serving as a school manager [5]. Researchers identified different instructional leader's role in their studies. For instance, McEwan in [9] has identified instructional leaders role as establishing clear instructional goals, being resourceful for staff, creating a school culture and climate conducive to learning, communicating the vision and mission of the school, setting high expectations for staff, developing teacher leaders, maintaining positive attitudes toward students, staff, and parents (in the same way Leithwood and Riehl in [15] noted, four characteristics and practices for effective principals which seeming to matter the most: setting directions that secure the physical environment and achieve high academic standards, developing people to use effective instructional strategies and interventions, redesigning the organization to include teachers and parents in decision-making, and managing the curriculum effectively by staffing the school with teachers who align with the mission and direction and buffering them from distractions.

According to [3] the principals need to have the competence to: create a shared vision and clear goals for their schools and ensure continuous progress toward achieving the goals; support the implementation of high-quality standards based instruction that results in higher levels of achievement for all students; provide opportunities for all members of the school community to build their capacity and participate in important school decisions; allocate resources and manage school operations in order to ensure a safe and productive learning environment and engage parents and community members in the educational process and create an environment where community resources support student learning, achievement and well being. This implies that the role of instructional leadership is pivotal in creating conducive learning atmosphere in the school.

\subsection{Instructional Leadership Models}

Many conceptual models of instructional leadership (e.g., [11] [12] [16]) have emerged from the studies on instructional leadership by studying the behavior of principals whose schools are perceived as effective schools. The instructional leadership model developed by [11] using qualitative research with primary heads of small schools in England and Wales found three strategies that are particularly effective in improving teaching and learning: modeling - in which principals used their teaching as an example of what and how to do things, work alongside staff in their classrooms, coaching staff and consciously used assemblies as occasions when they could promote and reinforce educational values and practices; in monitoring the heads look at teachers' weekly plans, visiting classrooms, examining samples of pupils' work, observing the implementation of school policies, reviewing test and assessment, evaluating pupil, class and school levels of performance and progress. While, in 
professional dialogue was developed through staff meetings, preparing curricular policies together, reviewing practice, looking at pupil learning data, joint planning meetings and general teamwork. The other model developed by [12] found two dimensions of instructional leadership (talking strategies with teachers to promote reflection and promoting professional growth). Talking strategies with teachers to promote reflection dimension include: making suggestions, giving feedback, modeling, using inquiry and soliciting advice and opinions, and giving praise. In promoting professional growth dimension principals used six strategies including: emphasizing the study of teaching and learning; supporting collaboration efforts among educators; developing coaching relationships among educators; encouraging and supporting redesign of programs; applying the principles of adult learning, growth, and development to all phases of staff development; and implementing action research to inform instructional decision making. The third model discussed in this paper is Hallinger and Murphy's model [16] which found three dimensions for the instructional leadership role of the principal: defining the school's mission, managing the instructional program, and promoting a positive school learning climate. These three dimensions are further delineated into ten instructional leadership functions. Since it is the model that has been used most frequently in empirical investigations and similar in key respects to others referenced above, the model has therefore been chosen to serve as a framework for this study. Hallinger and Murphy's model conceptualization of instructional management is illustrated in Figure 1.

Defining the school vision and mission: Recent literature on effective leadership placed the act of defining the school's mission as the primary role of school leader. This dimension comprises two functions: framing the school's goals and communicating the school's goals [16]. These functions concern the principals' role in working with staff to ensure that the school has clear, measurable goals that are focused on academic progress of its students. It is also the principal's responsibility to communicate these goals so they are widely known and supported throughout the school community [14] [17]. It was argued by [18] that this dimension dose not assumes that the principal defines the school's mission alone; it does assume that the principal's responsibility is to ensure that the school has a clear academic mission and to communicate it to staff and he asserted that establishing a clear school mission was a key avenue through which principals influence school effectiveness. It was through this avenue is that principals' shaped teachers' expectations and students opportunity to learn in the school.

Managing curriculum and instructional program: As [16] revealed that the management of the instructional program focus on the coordination and control of the instruction and curriculum. According to these researchers this dimension incorporates three leadership functions: Coordinating curriculum, supervising instruction and Monitoring and evaluating learner progress which are elaborated below.

Coordinating curriculum: The instructional programme of the school includes the curricular and extra-curricular activities. According to [6] extra-curricular activities are not isolated from their curricular activities but supplement the formal educational programme and contribute to the general education of the child [6]. Furthermore,

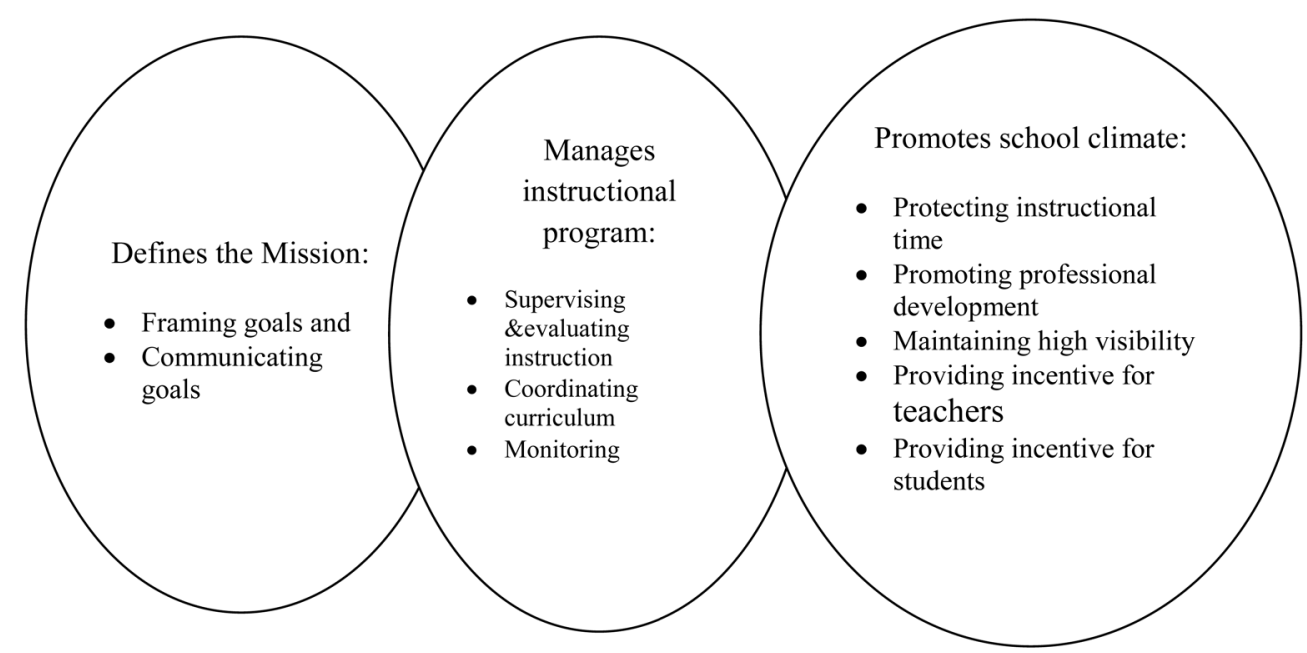

Figure 1. Dimension of instructional management/leadership. Source: adapted from Instructional management Behavior of Principals [16]. 
it was highlighted that students do different kinds of work in class and extra-curricular activities and as a result they spend quite a long time in school. These activities should be organized according to a feasible school timetable and should be convenient to students and teachers as they do activities in their free time [6]. Scholars [5] also claimed that principal as instructional leader is responsible for coordinating the curriculum across grade level and ensures that the school academic goals are translated into common curricular objectives and these are covered by teachers within the planned time frame.

Supervising instruction: It is one of the roles of principal, which is concerned with the improvement of instructional effectiveness. This role is used to stimulate staff development, to influence teacher behaviour in the classroom and to foster selection, development, use and evaluation of good instructional approaches and materials [5]. Classroom observation is one of the most powerful tools to collect information on students learning progress through random checking of homework and notebooks and interviews of selected students. Moreover, it was asserted that visiting classrooms allowed the principal to recognize opportunities for improving the technical aspects of instruction [5].

Monitoring and evaluating learner progress: School principals as instructional leaders along with teachers become engaged in monitoring learners' progress closely and frequently by means of evaluating tests and examinations. Using the results the principal provides support to both learners and educators to improve as well as to help parents understand where and why improvement is needed [6] [19]. The leader, thus, play a great role in monitoring students progress by providing teachers with test results in a timely and useful manner and discuss the result with the staff as a whole and with grade level an individual teachers [16].

Promoting positive school learning climate: Promoting a positive school learning climate viewed as one dimension of instructional leadership and serves the principal to influence the social organization and thereby establish environment that supports the instructional process [19]. It was highlighted by [16] that an effective instructional leader can promote a positive school learning climate by protecting instructional time, promoting professional development, maintaining high visibility, providing incentive for teachers and for learner. Under this dimension [16] identified the following five roles that instructional leaders need to perform.

1) Protecting instructional time: research conducted during the late 1970s and 1980s indicates the substantial effects of time on students learning [16]. Teacher's classroom management and instructional skills are not used optimally if instruction is frequently interrupted by announcements, tardy students and requests from the office. The principal can control this area of activity through the development and enforcement of school wide policies. Principals who successfully implement policies that limit interruption of class room learning time can increase allocated learning time and student achievement.

2) Providing incentive for teachers an important part of the principal's role in creating a positive learning climate involves setting up work structure that rewards and recognizes teachers for their efforts.

3) Providing incentive for learners: this principal's role can create a school climate in which students value academic achievement by frequently rewarding and recognizing students' academic achievement both within the class and before the school as a whole. Thus, principal is a key factor in linking the class rooms and school reward system, ensuring that they are mutually supportive.

4) Promoting professional development: principals need to promote professional development through organizing and leading in-service training activities and ensure that staff development activities are closely linked to school goals [16]. For instance, [20] asserted that the principal needs to create opportunities for professional development and growth of the staff. The focus of the instructional leader should be more orientated to staff development than to performance appraisal. This may enrich the teaching experience of educators or motivating them to attend such programmes [19].

5) Maintaining high visibility: high visibility of principal's in school campus and in classrooms increases interaction between the principal and students as well as with teachers. Instructional leaders are expected to spend most of their time dealing strictly with curricula matters rather than administrative functions. Hence to have credibility as an instructional leader, the principal should also be a practicing teacher. For example, in the United Kingdom, most principals spend an average of twenty percent of their time in a week on teaching [21]. Similarly, [13] explains instructional leadership as an active, collaborative form of leadership where the principal works with teachers and students to shape the school as workplace in relation to shared goals. Similarly, for [21] leading the instructional programme of a school means a commitment to living and breathing a vision of success in teaching and learning that includes focusing on learning objectives, modeling behaviors of learning, and designing programmes and activities on instruction. 
Research design: To conduct this study a qualitative case study approach was used. Researchers (e.g., [12] [22]) have stated that qualitative research explores attitude, behavior and experience through multiple forms of data, such as interviews, observation and documents, rather than rely on a single data source. Other researcher [23] asserted that in qualitative research the researcher is the key instrument, the data are collected in verbal form rather than numerical, data are analyzed inductively and researchers are concerned with the process rather than simply with without or products. A case study is thus appropriate for this study since it strives to portray "what it is like" to be in a particular situation, to catch the close up reality and "thick description" of participants' lived experiences of, thoughts about and feelings for, a situation and with a rich and vivid description of events relevant to the case and focuses on individual actors or groups of actors, and seeks to understand their perceptions of events [24].

Participant selection: For this study purposive sampling was used to select informants. The idea behind qualitative research is to purposefully select participants or sites that will best help the researcher understand the problem and the research question [25]. Accordingly, school principals (principal and deputy principal), two head of departments, two teachers, and students' council were selected as the sources of the data for the study. Students' council were interviewed as a group because they were the representative of students and have more work relation with the principal and can give adequate information regarding instructional leadership role of the principal in their school.

Site selection: In qualitative research it is appropriate to conduct the study in naturalistic settings [23]. Thus, the site for the study is Shambu primary school which is found in Shambu town, Horo Guduru Wollega Zone, Oromia regional state which found about 315 kms away from Addis Ababa the capital city of the Ethiopia as well as the Oromia region. The school is one of the six government primary schools found at Shambu town administration. The school was selected because of its longevity in its establishment (1930) and the first school that started secular education in Horo Guduru the then Awuraja now the zone. Moreover, the school has many staff than others in the zone.

Access to the school: A letter of permission to conduct research at the school was written to Shambu Primary School. After I got acceptance to conduct the research the purpose and ethical considerations of the study were clearly explained to respondents. Then, the principals and the teachers signed consent forms to indicate that they were not pressured to take part in the study and that they agreed with all the conditions set by the researcher.

Data collection tools: Three qualitative data collection tools: interview, observation and document analysis were employed. Accordingly, interview was conducted with principal and academic deputy principal, two heads of departments and two teachers. The group interview was conducted with students' council.

Interview as data gathering tool: In social research there are many types of interviews. The most common of these are structured; semi structured; and unstructured interviews [22]. For the purpose of this study I used semi-structured interview in which the researcher wants to know specific information which can be compared and contrasted with information gained in other interviews. To do this, the same guiding questions were asked in each interview. I conducted individual interview with a school principal and vice principal, two head of teachers and two teachers. No interview took longer than 40 minutes. Moreover, students' council was interviewed as a group. The advantage of this tool is that it can receive a wide range of responses during one meeting and helps people to remember issues they might otherwise have forgotten [22] [24].

Document analysis as data gathering tool: According to [23] the term document in qualitative research refers to "materials such as photographs, video films, memos, letters, diaries, clinical case records and memorabilia of all sorts that can be used as supplemental information". In this study documents such as: vision and mission of the school, instructional programs, teachers' and students' attendances, teachers' weekly and yearly lesson plans, time tables, School Improvement Program (SIP) were analyzed.

Observation: Observation of data affords the researcher the opportunity to gather "live" data from "live" situations [23]. For the purpose of this study I observed availability of instructional materials that supports the teaching and learning activities such as: laboratory, computer services, play grounds, library, pedagogical center, school building and class room conditions.

Data collection procedure: In qualitative research analysis of data involves collecting open ended data, based on asking general questions and developing an analysis from the information supplied by respondents [25]. Accordingly, the interviews were conducted in AfanOromo which is the working language of the region and the interviews were recorded using a tape recorder. Once the interview was concluded, each audio file were transcribed and translated to English language. Data obtained from the different interviews were analyzed using 
Tesch's approach stated in [25]. The transcripts were studied and, in the process, units, categories and themes were identified and the interpretation of the results then followed. Interview data were collected from different respondents (Table 1).

Data were closely examined in order to organize into categories on the basis of themes, concepts, or similar features [26]. I first listened to the recordings of each interview. The transcripts were read and re-read to get general understanding of the interviews and to identify categories and units of meanings. Accordingly, similar categories were then grouped together and arranged into themes. Themes were reduced by grouping related categories that show interrelationships. It is important to note that the classification of the data was not neutral in that it was guided by the research objectives [26]. Most of the themes that emerged from the interviews coincided with the literature of dimensions for instructional leadership. Accordingly, five themes such as: principal role in framing and communicating the school vision and mission; principal's involvement in managing of curriculum and instructional programs; principal's role in organizing staff development programmes; principal's role in create positive climate for teaching and learning; and principals' training. The themes that have been identified were discussed and supported with relevant quotations from the interviews.

Validity: Validity in qualitative inquiry has to do with being truthful. It refers to the bridge between a construct and the data [21] [26]. In this study I used triangulation strategy and thick descriptions to address validity concerns.

Reliability: Reliability in qualitative research deals with the consistency and dependability of the research findings. Dependability will be obtained through triangulation as well as a detailed report on the processes followed in the study so that future researchers may repeat the work. The taped interviews and transcription of the interviews will be stored and kept safely for verification purposes.

Ethical consideration: The right, needs, values and desires of their informant(s) were secured. In line to this, I informed the research objectives for informants so that they are clearly understood the informants (including a description of how data will be used), are search exemption form was filled, they also informed about the data collection devices and activities and the final decision regarding informant anonymity will rest with the informant.

\subsection{Data Analysis and Presentation}

Data analysis from Observation-I made observations at Shambu government primary school from January, 22 to February, 6/2014. A discussion of the observations was as follows: The school provides the teaching learning in two shifts (8:00 am to 12:00 am and 12:15 pm to 5:15 pm). The school had eight blocks of which four of them are used for class rooms. All blocks were made up of wood and mud. Some doors and windows were broken and needs maintenances. The block of administrative office has three rooms of which one is the office of principal. The school hadn't laboratory and play grounds and sport fields. The library was poorly resourced and mostly closed. In the pedagogical center there are different teaching aids such as graphs, charts and pictures. The meeting

Table 1. Respondents’ overview.

\begin{tabular}{|c|c|c|c|c|c|}
\hline \multirow{3}{*}{ Respondents } & \multirow{3}{*}{ Age } & \multicolumn{4}{|c|}{ Respondents' characteristics } \\
\hline & & \multicolumn{2}{|c|}{ Sex } & \multirow{2}{*}{ Qualification } & \multirow{2}{*}{ Specialization } \\
\hline & & M & $\mathrm{F}$ & & \\
\hline \multirow{2}{*}{$\begin{array}{c}\text { Principal \& deputy } \\
\text { principal }\end{array}$} & 56 & 1 & - & Diploma & Biology \\
\hline & 31 & 1 & - & Diploma & Math \\
\hline \multirow{2}{*}{ Head of department } & 45 & 1 & & Degree & English \\
\hline & 52 & & 1 & Diploma & Math \\
\hline \multirow{2}{*}{ Teachers } & 57 & 1 & & Diploma & Physics \\
\hline & 48 & & 1 & Diploma & Biology \\
\hline Students' council & & 4 & 3 & & \\
\hline Total & & 8 & 5 & & \\
\hline
\end{tabular}


hall and four class rooms were totally closed because of lack of maintenance. In the office there was one computer with a printer and some data were posted in the office. The two deputy principals were working in one office. Different data such as: time table, lists of different committee with their members such as school board, parent teacher association (PTA), continuous professional development (CPD) and school improvement program (SIP) were posted in the office. The observation result revealed that the instructional resources that support teaching and learning activities were inadequate and the school was poorly attractive. This can affect the implementation of school objectives and academic achievement of students.

Document analysis: Under document analysis issues such as schools' vision and mission, timetables, teachers' and students' attendances, lesson plan, yearly plan for curricular and extracurricular activities and school improvement program were analyzed and discussed.

Schools' vision and mission: The school had vision and mission statements. The analysis revealed that the vision and mission of the school was not revised in this year and it was similar to the last year.

Timetables: The school had posted yearly instructional dates which were adopted by education bureau, and weekly class instructional schedule, and exam times in the office of the vice principals, staff office and in each of the class room. The researcher came to the conclusion that the school used time tables as monitoring device for instructional activities.

Teachers' and students' attendances: The school had both teachers' and students' attendance sheets. From teachers' attendance it was observed that there was teachers' absenteeism from the school. This implies that there was wastage of teaching time in the school.

Teachers' lesson plan: Teachers' yearly lesson plans were documented in their respective department and the copy were found in academic vice principal office. Weekly lesson plans were checked by heads of the department and academic vice principal. This implies that the involvement of school principal in monitoring and controlling the implementation of curriculum activities was left to head of departments and vice principal.

Yearly plan for curricular and extracurricular activities: The school had curricular and extra-curricular activities plans. The analysis revealed that out of seventeen extra-curricular activities organized in the school in this year only eight of them were functional. This indicates that the implementation of extra-curricular activities in the school was unsatisfactory. This can hampered the interest and creativity of learners in the school.

School improvement program (SIP) documents: The school had school improvement program (SIP) document which is led by the school principal. However, the analysis of the document showed that the school SIP committee was not effectively functional. The activities that were carried out by SIP in the academic year of 2013/14 were that some part of school fence and few classrooms were repaired. This implies that the school leader was less effective in mobilizing the community to fund the school and make the school more attractive for teaching and learning.

Interview data: As stated by [25] data analysis involves collecting open ended data, based on asking general questions and developing an analysis from the information supplied by respondents. Data obtained from the different interviewees were analyzed and discussed in part. Accordingly, five themes such as: principal role in framing and communicating the school vision and mission; principal's involvement in managing of curriculum and instructional programs; principal's role in organizing staff development programmes; principal's role in creating positive climate for teaching and learning; and the training needs for the principals' were developed. The themes that have been identified were discussed and supported with relevant quotations from the interviews.

\subsection{Research Findings and Implications}

From the analyzed documents, observation made, and interviews data the researcher derived the following as the major findings of this study:

1) Principal's role in framing and communicating the school vision and mission.

The interviews from all respondents and document analysis revealed that the school has vision and mission. However, the principal gave less emphasis to the involvement of stakeholders in formulation of the school vision and mission and regularly communicating the vision and missions clearly to teachers and students. This view is highlighted by respondents as:

"Yes the school has vision and mission... I read it in principal's office... and also principals told us on meeting of the beginning year as teachers have to plan to improve students result and also students have to plan to improve their results... the awareness teachers and students had toward the mission of the school wasn't equal." 
Teacher (2)

"Yes we have-it was on the paper- and not renewed-on the staff meeting we heard similar saying from year to, year." Department head (b)

As scholars (e.g. [16] [19]) one of the instructional leadership function is formulating and defining a clear mission, goals, objectives and setting together with the staff members and communicating to stakeholders to realize effective teaching and learning.

The involvement of stakeholders in the process of formulating the vision and mission of the school can promote the sense of ownership of them. In other words, if the principal does not involve the stakeholders in the process of formulation of school's vision and mission people direct their attention to different goals, which may contribute to poor school achievement.

2) Principal's role in managing and monitoring curriculum and instructional program.

a) Managing the curriculum: The interviews revealed that the management of curriculum and instructional programs is a shared responsibility of principal, deputy principals and head of departments. This view is highlighted by respondents:

“...in our school it is not only the principal that manage, monitor, supervise and evaluates the curriculum and instructional programs... but also heads of departments and vice principals. Mostly HoDs and academic vice principal check teachers' weekly lesson plans.” Principal (II)

Similarly one of the respondents stated as “...managing, monitoring and monitoring curriculum implementation and instructional program is a collaborate effort of principals, deputy principals and head of department. Mostly deputy Principal and head of departments-monitor teaching-learning activities by checking teachers' lesson plan, discuss with students and teachers.” Department head (a)

From the foregoing evidences the management and monitoring of instructional programs were mostly lefts to deputy principal and head of department. Moreover, it was observed from the document analysis and information obtained from principals that out of seventeen extras-curricular activities organized in the school only eight of them were functional. This implies that the implementation of extra- curricular activities were unsatisfactory. This can hampered the interest and creativity of learners in the school.

b) Supervising instruction: According to [5] have noted, one of the of principal's role as instructional leader is evaluating instruction by conducting formal observation in classroom on a regular basis and ensuring that classroom objectives of teachers are consistent with the stated goals of the school. However, the interviews revealed that the supervisory role of school principal's was usually focuses on performance evaluation of the teachers. As the respondents explain:

"principal, deputy principals, and head of departments have conducted class visit... Mostly they supervise the class at the end of each semester for teachers' performance evaluation only." (Teacher 1)

From respondents view the supervision and evaluation were usually not to provide continues support to teachers and evaluate students' progress. This may indicate that the school leaders gave high consideration for performance evaluation which served for administrative purpose rather than formative evaluation that enable teachers to develop their profession growth and students learning progress.

3) Principal's role in staff development program: The interviews depicted that principal as instructional leader did not give emphasis for professional growth of teachers in the school. Various respondents had the following remarks about the staff development of their school as:

"There was no training and workshops organized in the school. Mostly trainings were designed at woreda or zone level. I haven't got any trainings and workshops for the past five years. I am teaching with the previous training that I had.” Teacher (1)

One of the principals says that “...last year Shambu teaches college gave trainings for some mathematics and science teachers on methods of teaching and evaluation. This year we hadn't conducted any training and workshops for teachers. ...training and workshops require budget ...we haven't budget to organize trainings and workshops.” Principal (I)

Form the above extracts of the interviews the staff development was neglected and the principal of the school may not in position to facilitate and organize staff development in school.

[20] asserted that the principal needs to create opportunities for professional development and growth of the staff. In order to improve the quality of teaching and learning, it is therefore imperative that the principals should promote staff development programmes in schools. Thus, the researcher came up with the conclusion that although the education and training policy places even greater importance on the need for professional de- 
velopment, it is the most neglected activity in the schools.

4) Principals' role in creating positive climate for teaching and learning.

a) Motivating teachers and students: One of the roles of instructional leader, in creating positive school climate of teaching and learning is motivating teachers and students by providing rewards for their good performance. Regarding this issue the data obtained from respondents showed that the culture of rewarding of teachers has recently started in their school. However, the evaluation criteria were developed at top and discourage those hard workers on the instructional activities. In elaborating this, the respondents had this to say:

“...the evaluation criteria for rewards were developed at top level education office. The school is only the implementer. The criteria gave less emphasis for direct teaching and learning activities. ...you see ...sometimes those who were rewarded were not accepted by their students in their teaching in class." Department head (b)

"...the overall evaluation of different activities... teaching and learning is one of the criteria for evaluation of teacher's reward. The evaluation criteria were developed at education office we are implementing it." Principal (I)

All of the respondents agreed that the students' reward system was convincing and based on their exam result which encourages students to work hard. From the obtained interviews data it was found that the evaluation criteria for teachers' reward were a top-down which may not fit with the school context. As a result teachers who devoted more on actual teaching and learning activities may not satisfied on reward system of the school.

b) Protecting teaching time: One of the instructional leader's roles is protecting instructional time. However, the finding of the study depicted that the learning time was disrupted for different reasons. This is evidenced by respondents as:

“...the implementation of the curriculum was not going as we planned. ...the teaching learning is interrupted for different reasons.-teachers and students were called for meetings by local administrators and education office.” Teacher (2)

This idea also confirmed by other respondent as:

"...the interruption of teaching and learning is a serious problem to cover the yearly curriculum and for the effective of teaching and learning ...because teachers are stressed to cover the curriculum and students are loaded and hate to come to school on their free time for tutorial classes." Principal (I)

Similarly the group discussion made with students showed that students were overloaded to compensate the interrupted instructional time on opposite shifts and weekends. Furthermore, teachers forced them to copy from the text books. The interruption of teaching and learning time was a serious problem which affects quality of education and students' academic achievement.

c) Principals' role in providing instructional resources: As noted by different researchers (see [19] [28]) for the effective management of the instructional program of a school, physical resources such as classrooms, laboratories, libraries, stationeries and instructional aids are important for the culture of teaching and learning and the achievement of instructional objectives. The observation made and the interviews obtained from principals, teachers and students revealed that the availability of instructional resources in the school was unsatisfactory. These views were highlighted by respondents as:

"The provision of instructional materials were very poor... the exam was written on the board... there is no duplicating machine. We haven't laboratory room... students were mostly learning theory from text books." Teacher (2)

This idea also confirmed by other respondent as:

"It is a difficult issue... having sufficient instructional resources imply that the school has sufficient funds to purchase the materials. ...although student-text book ratio was improved still there is shortages. We don't have laboratory ... play grounds ..., the school have only one computer... the problem is beyond the school capacity." Principal (I)

Similarly the focus group discussion conducted with students showed that students learning activities were hampered by lack of instructional resources in their school. Expressing this view the group discussion participants noted:

“...we haven't text books per each for all subjects ... we haven't laboratory ... We are learning only theory... we haven't play grounds... this year we haven't attend teaching through the radio... we didn't know the reason... library is not always opened."

From the foregoing data and discussion the school was poorly resourced with instructional materials. Lack of these instructional materials might be emanated from lack of principals' leadership skills to generate funds and 
unable to create links with different stakeholders.

d) Principals visibility and presence for teachers and students: As noted by different researchers the principal needs to be highly visible on the campus and even in classrooms. The principal models, values and practices that create a climate and support the continuous improvement of teaching and learning [17]. The data obtained from respondents showed that although the principals (principal and deputy principals) were available in the school they spent most of their time on administrative tasks rather than instructional tasks. This was evidenced by the following extracts of interviews.

"...most of the time they are available in the school. Someone can find them mostly in their office ... holding meetings with staff and students... sometimes walking around and visiting classes. However, sometimes they were called out of school for meetings" Department head (b)

"....most of the time they are visible in the school... they are found in their offices... hold meetings and sometimes walking around.” Teacher (2)

It also confirmed by the principals that they were mostly visible in the school and engaged most of the time on school administrative tasks. One of the respondents of the principal expresses as:

“...I didn't teach students directly in actual class situation... I am engaged in many activities... hold different meetings in the school with staff, students, with local administrative... education office, parents. I spend most of my time in settling students' discipline problems, preparing reports, talk with parents and sometimes visit classes."

Form the foregoing data the visibility of principals in the schools by itself cannot create the positive climate of teaching and learning activities in the school unless principals spent more time on instructional issues rather than administrative tasks. Most structured observation studies reported that school principals tend to spend most of their time on managerial tasks unrelated to instruction [16].

5) Principals' training needs: All the respondents asserted that the lack of training of the principals hampered principal's roles as instructional leader. This was highlighted by the interviewees in the following extracts:

"Principals need to have training on school leadership... I am leading the school from experience. I haven't any training even workshop on school leadership in the past four years of my principal position." Principal (I)

"To me ...it is good if trained principals are assigned in principal positions ...leaders can change the worst into the best. Our principals are leading the school by experience." Department head (b)

According to [29] principalship is a specialist occupation that requires specific preparation. Similarly [3] stated that the principal is the leading professional in the school and the major role of the principal is providing professional leadership and management for a school.

From the data obtained it was found that lack of training of principals hampers successful attainment of the vision and missions of the school and lessen the commitment teachers have to their principal professional support.

\section{Conclusion}

The findings of the study showed that the instructional leadership role is mostly carried out by shared leadership and responsibilities among principal, deputy principals and head of departments. However, the school principals spent more of their time on administrative tasks rather than instructional tasks. This implies that there is unbalance between administrative tasks and instructional tasks of the principal's role. The finding of the study also disclosed that principal needs to engage in many activities as instructional leader to improve the teaching and learning. These activities include: the principal needs to set school vision, mission, goal and objectives with staff, clearly communicate the visions and mission to stakeholders and ensure that all members cooperate towards a common goal; principal as instructional leader needs to organize different trainings for staff development; principal as instructional leader needs to create positive climate for teaching and learning and to ensure effective teaching and learning in school; and to enhance quality education principal needs to have professional skills in school management and leadership.

\section{Recommendations}

Based on the findings and conclusions made in the study the researcher suggests some recommendations regarding how the principals could improve as instructional leader so as to enhance the quality of teaching and learning. 
1) Communicating a clear vision and mission to stakeholders.

Vision and mission guide the daily activities of the school and should therefore be formulated with the participation of all concerned bodies and renewed every year with the changing needs of the customers, need to be communicated effectively until all internalize it so that everyone understands, and have commitment for its implementation.

In the light of these views, I would like to recommend that the principal should involve teachers, students and the community in formulation of vision and mission and communicate to them and frequently evaluate their daily activities against what is stipulated in the mission statement. This approach could help all to internalize the school aims as their own and become more committed to its implementation.

2) Managing curriculum and instruction.

The findings of the study revealed that the management of curriculum and instructional programs in the school is a shared leadership and responsibility of principal, deputy principals and head of departments. However, the finding of the study revealed that the principal gave less consideration for extra-curricular activities, frequent supervision and supporting teachers and students that enable teachers to develop their profession growth and students' learning progress. In the light of this view I recommended that the principal has to practice clinical supervision, strengthen curricular and extra-curricular activities and monitor students' progress in collaboration with deputy principals, head of departments, teachers, students and parents.

3) Staff development.

The research finding revealed that the practice of teachers' professional developments in the school was unsatisfactory. One of the principal's roles is to plan and lead the processes of professional development and learning in accordance with school policy and the professional needs and aspirations of teachers, in keeping with the stages of their teaching careers. Working on staff development ensures the effective implementation of the school objectives and enhances education quality. Based on foregoing views I recommended that the principals should give attention to staff development through identifying training needs of teachers, planning, organizing and coordinating trainings in the school and enhancing teachers' capacity through workshops, seminars and inservice trainings. Similarly, the local administrative education office, the zone education department and the regional education bureau should emphasize on staff development programs.

4) Resource provisioning.

The research finding showed that the provision of teaching materials in the school was poor and unsatisfactory. Lack of these instructional materials might be emanated from lack of leadership capacity of principals to generate funds by creating linkages with different stakeholders and agencies. It was stated in Ethiopian education and training policy [1] that education is free up to the completion of general secondary education (grade 1 grade 10). However, it does not mean that the cost of education is covered only from government pocket. In order to make the school more effective, the community, parents, private institutions and non-government organizations should take part in supporting the school through financing.

Thus, the researcher would like to recommend that the principals should create fund raising strategies such as: bazaar in the school, fundraising proposals for different agencies, and strengthen school-community relations in order to maximize school budget for purchasing instructional materials. Moreover, the allocation of fiscal budget to the school by local government should be in accordance with the enrollment of students in the school.

5) Promoting positive instructional climate.

One of the roles of instructional leader is to create positive climate for teaching and learning. However, the research finding showed that the teachers were not satisfied with the teacher's reward system. This is due to the fact that the evaluation criteria for reward were a top-down approach which may not fit with the school context. Even though, the teaching and learning is a core task in the school, it was less emphasized. Thus, the principal should develop clear evaluation criteria that mostly focus on teaching tasks and has to be communicated to the staff. Similarly, the research finding revealed that interruption of teaching and learning time is a serious problem in the school. If not managed properly it can hamper the implementation of instructional programs and as a result it affects quality of education. Thus, I would like to recommend that the principal should protect teaching time through developing code of conduct for teachers and students in order to abide rules and regulations of the school. Besides to this the principal should hold meetings with teachers and students out of class time. Moreover, the principal should convince and work with the local administrative and education offices not to call teachers and students for meetings and trainings on school day.

6) Principal training. 
The research finding showed that the school principals were untrained in school leadership. As stated in different literatures and also by Ministry of education of Ethiopia [1], the principal is the leading professional in the school and the major role of the principal is providing professional leadership and management for a school. This implies that principals should be competent and skillful in order to lead the school. It is therefore important that the town administrative education office, zone education department and Oromia education bureau should work collaboratively on training of the principals in school leadership through workshops, on-job and off-job trainings to develop the capacity of principals in order to make the school leadership more effective.

\section{Suggestions for Future Research}

I suggested that future studies could include urban and rural schools, concerning principal's role in improving educational quality.

\section{Acknowledgements}

I am honored to take this opportunity to thank my instructor Getnet Tizazu (PhD) I greatly appreciate his critical advice, comments and encouragement he gives for his students. My thanks also go to Shambu Primary School administration and all respondents.

\section{References}

[1] Federal Democratic Republic of Ethiopia Ministry of Education (1994) Education and Training Policy. S. George Printing Press, Addis Ababa.

[2] Federal Democratic Republic of Ethiopia Ministry of Education (2008) General Education Quality Improvement Package (GEQIP).

[3] Federal Democratic Republic of Ethiopia Ministry of Education (2012) National Professional Standard for School Principals. MoE, Addis Ababa.

[4] Pont, B., Nusha, D. and Morman, H. (2008) Improving School Leadership Vol. 1: Policy and Practice OECD. Source

[5] Yunas, M. and Iqbal, M. (2013) Dimensions of Instructional Leadership Roles of Principals. Interdisciplinary Journal of Contemporary Research in Business, 4, 629-637.

[6] UNESCO (2005) School Management a Training Manual for Educational Management. UNESCO International Institute for Capacity Building in Africa.

[7] Taole, M. (2013) Exploring Principals Role in Providing Instructional Leadership in Rural High Schools in South Africa. Studies of Tribes and Tribals, 11, 75-82.

[8] Federal Democratic Republic of Ethiopia Ministry of Education (2010) Education Sector Development Program IV (ESDP IV) 2010/2011-2014/2015 Action Plan.

[9] Tedla, B.A. (2012) Instructional Leadership and School Climate: A Case Study of Secondary School in Eriteria. Literacy Information and Computer Education Journal Special Issues, 1, 755-764.

[10] Mitchell, C. and Castle, J.B. (2005) The Instructional Role of Elementary School Principals. Canadian Journal of Education, 28, 409-433. http://dx.doi.org/10.2307/4126477

[11] Southworth, G. (2002) Instructional Leadership in Schools: Reflections and Empirical Evidence. School Leadership \& Management, 22, 73-91. http://dx.doi.org/10.1080/13632430220143042

[12] Blasé, J. and Blasé, J. (2000) Effective Instructional Leadership: Teachers’ Perspectives on How Principals Promote Teaching and Learning in Schools. Journal of Educational Administration, 38, 130-141. http://dx.doi.org/10.1108/09578230010320082

[13] Mestry, R. (2013) The Innovative Role of the Principal as Instructional Leader: A Prerequisite for High Student Achievement? International Proceedings of Economics Development \& Research, 60, 119-123.

[14] Bush, T. and Glover, D. (2003) School Leadership: Concepts and Evidence. A Review of Literature Carried out for National College for School Leadership. National College for School Leadership, Nottingham.

[15] Ylimakia, R., Jacobsona, S.L. and Drysdaleb, L. (2007) Making a Difference in Challenging, High-Poverty Schools: Successful Principals in the USA, England, and Australia. School Effectiveness and School Improvement, 18, 361-381. http://dx.doi.org/10.1080/09243450701712486

[16] Hallinger, P. and Murphy, J. (1985) Assessing the Instructional Management Behaviour of Principals. The Elementary School Journal, 86, 217-247. http://dx.doi.org/10.1086/461445 
[17] Hallinger, P. (2009) Leadership for 21st Century Schools: From Instructional Leadership to Leadership for Learning. Public Lecture Series of the Hong Kong Institute of Education on 23 September 2009.

[18] Hallinger, P. (2010) Geteways to Leading Learning Leading Educational Change. APCLC Monograph Series, 2010, No. 1. www.ied.edu.hk/apclc

[19] Kruger, A.G. (2003) Instructional Leadership: The Impact on the Culture of Teaching and Learning in Two Effective Secondary Schools. South African Journal of Education, 23, 206-211.

[20] Du Four, R. and Berkey, T. (1995) The Principal as Staff Developer. Journal of Staff Development, 16, 2-6.

[21] Phillips, J.A. (2014) Manager-Administrator to Instructional Leader Shift in the Role of the School Principal. http://peoplelearn.homestead.com/PrincipaInstructLeader.htm

[22] Dawson, C. (2007) A Practical Guide to Research Methods. 3rd Edition, Spring Hill House, Oxford.

[23] Bogdan, R.C. and Biklen, S.N. (2007) Qualitative Research for Education an Introduction to Theories and Methods. 5th Edition, Pearson, Boston.

[24] Cohen, L., Manion, L. and Morrison, K. (2000) Research Methods in Education. 5th Edition, Routledge Falmer, London. http://dx.doi.org/10.4324/9780203224342

[25] Creswell, J.W. (2009) Research Design Qualitative, Quantitative and Mixed Methods Approaches. 3rd Edition, Sage, Los Angeles.

[26] Neuman, W.L. (2007) Basics of Social Research Qualitative and Quantitative Approaches. Allyn and Bacon, Boston.

[27] Marks, M. and Printy, M. (2003) Principal Leadership and School Performance: An Integration of Transformational and Instructional Leadership. Educational Administration Quarterly, 39, 370-397. http://dx.doi.org/10.1177/0013161X03253412

[28] Andrews, R.L., Basom, R.M. and Basom, M. (1994) Instructional Leadership: Supervision That Makes a Difference. Theory in Practice, 30, 97-101. http://dx.doi.org/10.1080/00405849109543484

[29] Bush, T. (2008) Leadership and Management in Education. Sage, Los Angeles. 